\title{
CrystEngComm
}

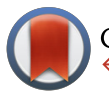

CrossMark

\&click for updates

Cite this: CrystEngComm, 2016, 18, 704

Received 28th October 2015, Accepted 10th December 2015

DOI: $10.1039 / \mathrm{c} 5 \mathrm{ce} 02109$

www.rsc.org/crystengcomm

\section{Isoskeletal Schiff base polynuclear coordination clusters: synthetic and theoretical aspects $\dagger$}

\author{
Kieran Griffiths, Vassiliki N. Dokorou, John Spencer, Alaa Abdul-Sada, \\ Alfredo Vargas* and George E. Kostakis*
}

\begin{abstract}
This work addresses and enlightens synthetic aspects derived from our effort to systematically construct isoskeletal tetranuclear coordination clusters (CCs) of the general formula $\left[\mathrm{TR}_{2} \mathrm{Ln}_{2}(\mathrm{LX})_{4}\left(\mathrm{NO}_{3}\right)_{2}(\mathrm{solv})_{2}\right]$ possessing a specific defected dicubane topology, utilizing various substituted Schiff base organic ligands $\left(\mathrm{H}_{2} \mathrm{LX}\right)$ and $\mathrm{Ni} / \mathrm{CO}$ " and Dy $(\mathrm{OTf})_{3}$ salts. Our synthetic work is further supported by DFT studies.
\end{abstract}

\section{Introduction}

The chemistry of polynuclear coordination clusters $(\mathrm{CCs})^{1,2}$ of paramagnetic $3 \mathrm{~d}$ and/or $4 \mathrm{f}$ metals is an area of research that offers many interdisciplinary opportunities to connect with chemistry, physics, biology and materials science. Aesthetically pleasing structures have been reported; $;^{3-12}$ moreover, several research groups have showcased the relevance of CCs in a variety of fields such as catalysis, ${ }^{13-16}$ biology, ${ }^{17}$ luminescence, ${ }^{18-20}$ magnetic resonance ${ }^{21}$ and molecular magnetism. ${ }^{22,23}$

Several organic ligands have been employed to build new $\mathrm{CCs}^{24}$ and among them Schiff base ligands are widely employed to give access to a plethora of compounds with unprecedented topologies and interesting magnetic properties. ${ }^{5,8,9,25-45}$ The reason for the widespread selection of Schiff bases as ligands for the construction of polynuclear CCs is manifold: a) their facile synthesis and readily tunable structures obtainable in high yields; b) structural diversity is assured given the availability of a plethora of carbonyl and amine precursors; and c) the accessibility of several coordination sites allows for varied binding modes, although the exact structure and composition of the final product are invariably unpredictable. $(E)-2-(2-$ Hydroxy-3-methoxybenzylideneamino)phenol $\mathbf{H}_{2} \mathbf{L 1}$ (Scheme 1, left) is derived from the condensation of $o$-vanillin and 2-aminophenol and several CCs bearing this ligand have been reported. ${ }^{46-57}$ The blending of this ligand with $\mathrm{Co}^{\mathrm{II}}$ or $\mathrm{Ni}^{\mathrm{II}}$ and $4 \mathrm{f}$ nitrate salts results in tetranuclear $\mathrm{CCs}^{46,47}$ of the general formula $\left[\mathrm{TR}_{2} \mathrm{Ln}_{2} \mathbf{L 1}_{4}\left(\mathrm{NO}_{3}\right)_{2}(\operatorname{solv})_{2}\right]$, where $\mathrm{TR}$ is $\mathrm{Co}^{\mathrm{II}}$ or $\mathrm{Ni}^{\mathrm{II}}$, Ln is ${ }^{\text {DIII }}$ or $\mathrm{Tb}^{\mathrm{III}}$ and solv is THF or DMF, possessing a

Department of Chemistry, School of Life Sciences, University of Sussex, Brighton BN1 9QJ, UK. E-mail: Alfredo.Vargas@sussex.ac.uk, G.Kostakis@sussex.ac.uk $\dagger$ Electronic supplementary information (ESI) available: Crystallographic table of all compounds; ESI-MS of compounds 7, 10 and 16; protocols for thermal and microwave-mediated synthesis of ligands; ${ }^{1} \mathrm{H}$ and ${ }^{13} \mathrm{C}$ NMR of ligands; FT-IR of ligands $\mathbf{H}_{2} \mathbf{L 1}-\mathbf{H}_{2} \mathbf{L 2 0}$. CCDC 1406218-1406237. For ESI and crystallographic data in CIF or other electronic format see DOI: 10.1039/c5ce02109j defected dicubane or "butterfly" 58 core (Scheme 1, middle) or a 2,3M4-1 (Scheme 1, right) ${ }^{48,59,60}$ topology with the $4 \mathrm{f}$ ions in the wings and the $3 \mathrm{~d}$ metal in the hinge. This topology represents one of the most common structural motifs in magneto chemistry, and CCs of this type have been wellstudied and their behaviour is often very well-understood. ${ }^{46,47}$ From a structural point of view, it is worth emphasizing that $\mathbf{H}_{2} \mathrm{~L} 1$ supports this topology in the absence of any additional bridging atom.

For a long time, synthetic chemists have employed new organic ligands along with $3 \mathrm{~d}$ and/or $4 \mathrm{f}$ centres, under various reaction conditions, to afford new polynuclear species; however, few researchers have focused their efforts on tuning the periphery of the organic ligands and studying its influence on the properties of the final product. For example, Murugesu et $a .^{35}$ reported a 7 -fold enhancement of the energy barrier, $U_{\text {eff, }}$ of a $\mathrm{Dy}^{\text {III }}{ }_{2}$ that behaves as Single Molecule Magnet (SMM), by introducing electron-withdrawing terminal ligands.

Having all this in mind, we initiated a project towards the synthesis of tetranuclear CCs of the general formula $\left[\mathrm{TR}_{2} \mathrm{Ln}_{2} \mathrm{L1}_{4}\left(\mathrm{NO}_{3}\right)_{2}(\mathrm{solv})_{2}\right]$, which possess the 2,3M4-1 topology, using $\mathrm{Co}^{\mathrm{II}}$ or $\mathrm{Ni}^{\mathrm{II}}$ and $4 \mathrm{f}$ ions and substituted Schiff base ligands, similar to $\mathbf{H}_{2} \mathbf{L 1}$ (Scheme 2, left) in the presence or absence of substituted monocarboxylates as co-ligands (Scheme 2, right). The interest for this specific motif, which is supported only by the organic ligand in the absence of any additional bridging atom, is manifold: a) these types of

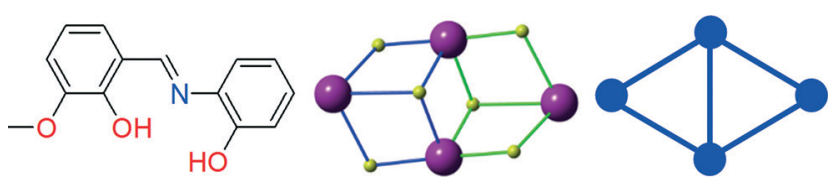

Scheme 1 (left) The (E)-2-(2-hydroxy-3-methoxybenzylideneamino)phenol $\mathrm{H}_{2} \mathrm{~L}$ 1 ligand, (middle) the defected dicubane motif, and (right) the 2,3M4-1 topology. 

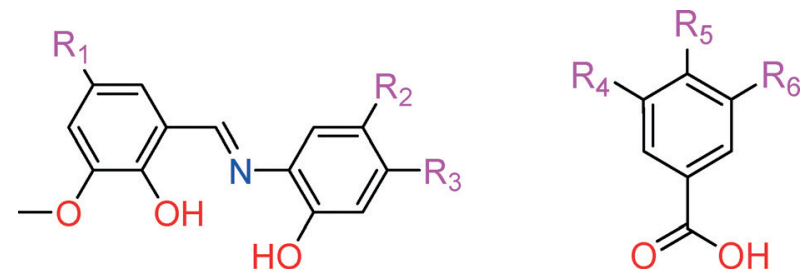

Scheme 2 (left) The substituted organic ligands used in this work $\mathrm{R}_{1}=$ $\mathrm{H}, \mathrm{Br}$, allyl, $\mathrm{NO}_{2} ; \mathrm{R}_{2}=\mathrm{H}, \mathrm{Cl}, \mathrm{C}_{6} \mathrm{H}_{5} ; \mathrm{R}_{3}=\mathrm{H}, \mathrm{NO}_{2} ; \mathrm{R}_{2}-\mathrm{R}_{3}=\mathrm{C}_{4} \mathrm{H}_{4}$; (right) the substituted monocarboxylates used in this work ( $M 1 R_{4}=R_{6}=N_{2}$; $\mathrm{R}_{5}=\mathrm{H} ; \mathrm{M} 2 \mathrm{R}_{4}=\mathrm{NO}_{2} ; \mathrm{R}_{5}=\mathrm{R}_{6}=\mathrm{H}$ ).

molecules exhibit SMM behaviour ${ }^{46,47}$ and thus it is anticipated that the introduction of electron-withdrawing groups would improve their magnetic properties. b) Replacement of the $3 \mathrm{~d}$ and $4 \mathrm{f}$ ions with luminescent elements such as $\mathrm{Zn}^{\text {II }}$ and $\mathrm{Eu}^{\mathrm{III}}$ or $\mathrm{Tb}^{\mathrm{III}}$, respectively, may lead to a new generation of materials with interesting optical properties. c) We recently showed that three tetranuclear CCs formulated as $\left[\mathrm{TR}_{2}{ }_{2} \mathrm{Dy}{ }_{2}{ }_{2}(\mathrm{L1})_{4}(\mathrm{EtOH})_{6}\right]\left(\mathrm{ClO}_{4}\right)_{2} \cdot 2(\mathrm{EtOH})$ where $\mathrm{TR}$ is $\mathrm{Co}^{\mathrm{II}}(\mathbf{1})$ or $\mathrm{Ni}^{\mathrm{II}}(2)$ and $\left[\mathrm{Ni}^{\mathrm{II}}{ }_{2} \mathrm{Dy}_{2}^{\mathrm{III}}{ }_{2}(\mathrm{L1})_{4} \mathrm{Cl}_{2}\left(\mathrm{CH}_{3} \mathrm{CN}\right)_{2}\right] \cdot 2\left(\mathrm{CH}_{3} \mathrm{CN}\right)$ (3) display efficient homogeneous catalytic behaviour in the roomtemperature synthesis of trans-4,5-diaminocyclopent-2-enones from 2-furaldehyde and primary or secondary amines under a non-inert atmosphere and thus, further tuning of the organic periphery may improve their catalytic performance. ${ }^{57} \mathrm{~d}$ ) More importantly, the possibility of exchanging the $3 \mathrm{~d}$ and/or the $4 \mathrm{f}$ elements with diamagnetic metal centres and retaining at the same time the structural topology in the solution gives the opportunity to study these molecules in the solid and/or solution state with several spectroscopic techniques such as NMR $\left({ }^{1} \mathrm{H},{ }^{13} \mathrm{C},{ }^{89} \mathrm{Y}\right)$ or EPR for the Gd species.

Adopting the isoreticular concept, introduced by O'Keeffe and Yaghi in metal-organic framework chemistry, ${ }^{61}$ a terminology that is not valid for finite structures, and since the isostructural and isomorphous terms do not fully describe the targeted CCs, we introduce herein the term "isoskeletal", previously used to describe clusters that possess the same topology $^{62,63}$ or related organic structures with the same host framework but different guests, ${ }^{64,65}$ to describe the targeted CCs constructed from organic ligands that provide a similar coordination environment and have the same 2,3M4-1 topology. This work addresses and enlightens synthetic and theoretical aspects derived from our effort to systematically construct isoskeletal CCs of the general formula $\left[\mathrm{TR}_{2} \mathrm{Ln}_{2}(\mathbf{L X})_{4}\left(\mathrm{NO}_{3}\right)_{2}(\mathrm{solv})_{2}\right]$, possessing the desired 2,3M4-1 topology. Magnetic, luminescence and catalytic studies of a few of the reported compounds will be discussed in future articles. To the best of our knowledge, such a systematic synthetic and theoretical investigation for the given $\mathrm{Ni}^{\mathrm{II}}-\mathrm{Co}^{\mathrm{II}} / \mathrm{Dy}{ }^{\mathrm{III}}$ species bearing the 2,3M4-1 topology has never been carried out.

\section{Results and discussion}

The synthesis of the substituted organic molecules represents the initial synthetic part of this project. A typical synthesis of a Schiff base ligand takes place in an alcoholic solution in the presence or absence of a catalyst (acid or base), although other synthetic methods such as microwave-mediated ${ }^{66}$ or solvent-free mechanochemical synthesis ${ }^{67,68}$ can be employed. Our attempts to synthesize the substituted organic molecules bearing electron-withdrawing groups (Scheme 2, left) (Table 1, entries 2-20) via a typical synthesis, viz. reflux in alcoholic solution of equivalent amounts of the corresponding aldehyde and amine, resulted in the desired products, but in very low yields. Microwave-assisted organic synthesis (MAOS) enables the rapid synthesis of organic molecules, often with excellent yields and selectivity. Interestingly, by applying $\operatorname{MAOS}^{69,70}$ for the synthesis of the corresponding organic molecules, the yield increases drastically. In total, we synthesized 19 new organic ligands (Table 1, entries 2-20) and we characterized via single crystal X-ray crystallography two examples, $\mathbf{H}_{2} \mathbf{L 3}$ and $\mathrm{H}_{2} \mathbf{L 1 9}$ (Fig. 1). Single crystal X-ray studies at $173 \mathrm{~K}$ reveal that both $\mathrm{H}_{2} \mathrm{~L} 3$ and $\mathrm{H}_{2} \mathrm{~L} 19$ are a mixture of keto-enol tautomers. In $\mathbf{H}_{2} \mathbf{L} 3$ (Fig. 1, above), where two molecules can be found in the asymmetric unit, the enol form of the ligand is indicative of the existence of protons $\mathrm{H} 3$ and H8A that could be freely refined with 22 and $23 \%$ chemical occupancy, respectively. However, to obtain a suitable structure solution, both protons were restrained to have $25 \%$ occupancy and their $\mathrm{O}-\mathrm{H}$ bond distance to be at $0.88 \AA$. The $\mathrm{C}-\mathrm{O}$ bond distances are 1.282(3) and 1.282(3) Å which are slightly higher than a typical $\mathrm{C}=\mathrm{O}$ double bond. Similarly, for ligand $\mathrm{H}_{2} \mathrm{~L} 19$, protons $\mathrm{H} 1$ and $\mathrm{H} 2$ (Fig. 1 below) could be freely refined and have $79 \%$ and $21 \%$ occupancies, indicating a 79/21 existence of the ketonic/ enolic form, while the $\mathrm{C}-\mathrm{O}$ bond distance is 1.285(2) A. These findings are in line with previously reported compounds. ${ }^{67}$ Solution studies $\left({ }^{1} \mathrm{H}\right.$ and ${ }^{13} \mathrm{C}$ NMR) of the synthesized compounds revealed the existence of both keto and enol forms.

Table 1 A list of all substituted Schiff bases synthesized for this study. $R_{1}$, $R_{2}$ and $R_{3}$ correspond to the substituted groups seen in Scheme 2 (left)

\begin{tabular}{|c|c|c|c|c|c|}
\hline Entry & & $\mathrm{R}_{1}$ & $\mathrm{R}_{2}$ & $\mathbf{R}_{3}$ & Yield (\%) \\
\hline 1 & $\mathrm{H}_{2} \mathrm{~L} 1$ & $\mathrm{H}$ & $\mathrm{H}$ & $\mathrm{H}$ & 95 \\
\hline 2 & $\mathrm{H}_{2} \mathrm{~L} 2$ & $\mathrm{H}$ & $\mathrm{H}$ & $\mathrm{NO}_{2}$ & $66[96]^{a}$ \\
\hline 3 & $\mathrm{H}_{2} \mathrm{L3}$ & $\mathrm{H}$ & $\mathrm{Cl}$ & $\mathrm{NO}_{2}$ & $76[95]^{a}$ \\
\hline 4 & $\mathrm{H}_{2} \mathrm{L4}$ & $\mathrm{H}$ & $\mathrm{C}_{6} \mathrm{H}_{5}$ & $\mathrm{H}$ & 91 \\
\hline 5 & $\mathrm{H}_{2} \mathrm{L5}$ & $\mathrm{H}$ & $\mathrm{C}_{4} \mathrm{H}_{4}$ & & 88 \\
\hline 6 & $\mathrm{H}_{2} \mathrm{L6}$ & $\mathrm{NO}_{2}$ & $\mathbf{H}$ & $\mathrm{H}$ & 93 \\
\hline 7 & $\mathrm{H}_{2} \mathbf{L} 7$ & $\mathrm{NO}_{2}$ & $\mathrm{H}$ & $\mathrm{NO}_{2}$ & 94 \\
\hline 8 & $\mathrm{H}_{2} \mathrm{L8}$ & $\mathrm{NO}_{2}$ & $\mathrm{Cl}$ & $\mathrm{NO}_{2}$ & 80 \\
\hline 9 & $\mathrm{H}_{2} \mathbf{L} 9$ & $\mathrm{NO}_{2}$ & $\mathrm{C}_{6} \mathrm{H}_{5}$ & $\mathrm{H}$ & 92 \\
\hline 10 & $\mathrm{H}_{2} \mathbf{L 1 0}$ & $\mathrm{NO}_{2}$ & $\mathrm{C}_{4} \mathrm{H}_{4}$ & & 74 \\
\hline 11 & $\mathrm{H}_{2} \mathrm{L11}$ & allyl & $\mathbf{H}$ & $\mathrm{H}$ & $70[98]^{a}$ \\
\hline 12 & $\mathrm{H}_{2} \mathrm{L12}$ & allyl & $\mathrm{H}$ & $\mathrm{NO}_{2}$ & 72 \\
\hline 13 & $\mathrm{H}_{2} \mathbf{L 1 3}$ & allyl & $\mathrm{Cl}$ & $\mathrm{NO}_{2}$ & 70 \\
\hline 14 & $\mathrm{H}_{2} \mathbf{L 1 4}$ & allyl & $\mathrm{C}_{6} \mathrm{H}_{5}$ & $\mathrm{H}$ & 69 \\
\hline 15 & $\mathrm{H}_{2} \mathrm{~L} 15$ & allyl & $\mathrm{C}_{4} \mathrm{H}_{4}$ & & $61[95]^{a}$ \\
\hline 16 & $\mathrm{H}_{2} \mathrm{L16}$ & $\mathrm{Br}$ & $\mathbf{H}$ & $\mathrm{H}$ & 84 \\
\hline 17 & $\mathbf{H}_{2} \mathbf{L 1 7}$ & $\mathrm{Br}$ & $\mathrm{H}$ & $\mathrm{NO}_{2}$ & 79 \\
\hline 18 & $\mathrm{H}_{2} \mathrm{L18}$ & $\mathrm{Br}$ & $\mathrm{Cl}$ & $\mathrm{NO}_{2}$ & $35[85]^{a}$ \\
\hline 19 & $\mathrm{H}_{2} \mathrm{~L} 19$ & $\mathrm{Br}$ & $\mathrm{C}_{6} \mathrm{H}_{5}$ & $\mathbf{H}$ & 83 \\
\hline 20 & $\mathrm{H}_{2} \mathrm{~L} 20$ & $\mathrm{Br}$ & $\mathrm{C}_{4} \mathrm{H}_{4}$ & & 79 \\
\hline
\end{tabular}

${ }^{a}$ MW technique. 

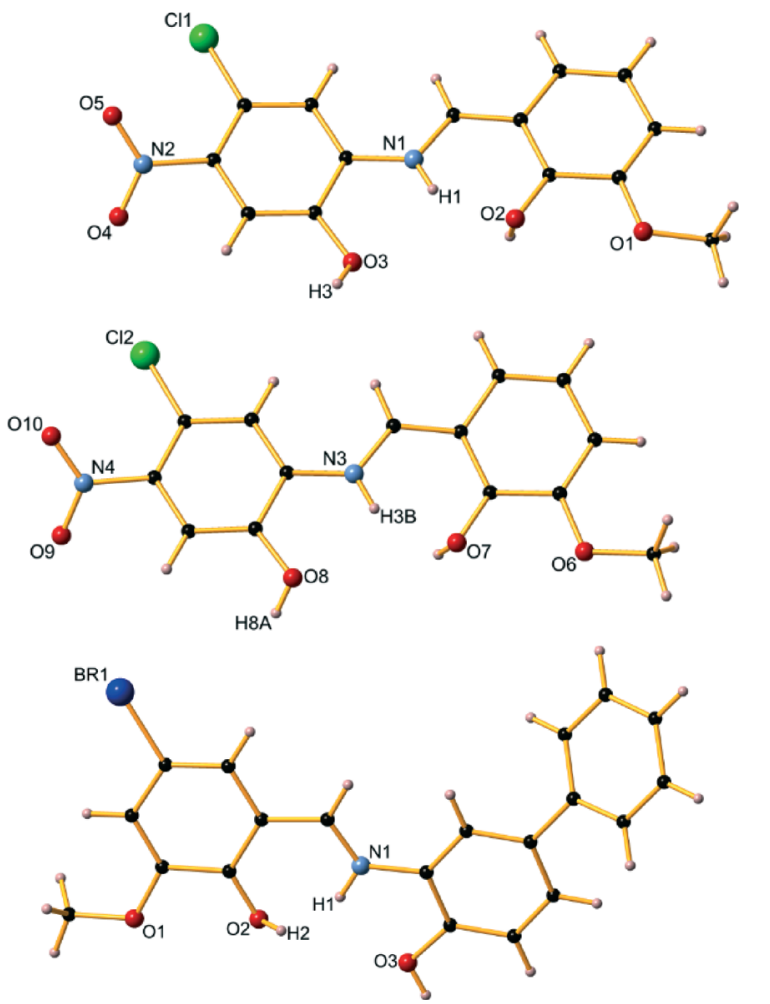

Fig. 1 A schematic representation of $\mathrm{H}_{2} \mathrm{L3}$ (up) and $\mathrm{H}_{2} \mathrm{~L} 19$ (bottom) ligands.

The synthesis of the targeted tetranuclear CCs represents the next part of this project. Based on the synthetic protocols that resulted in the isolation of the targeted tetranuclear CCs $\left[\mathrm{TR}_{2} \mathrm{Ln}_{2}(\mathbf{L X})_{4}\left(\mathrm{NO}_{3}\right)_{2}(\text { solv })_{2}\right],{ }^{57}$ and bearing in mind that a subtle change in the synthetic procedure may affect the shape, dimensionality and nuclearity of the final product, we screened several molecular ratios to isolate the corresponding targeted isoskeletal CCs. At this point, it is worth mentioning that in order to avoid complicating the synthetic procedures we employed only Dy(OTf $)_{3}$ as the lanthanide source. During this screening procedure several interesting and unexpected results were obtained, grouped and presented below.

\section{A) Oxidation}

The reaction of $\mathrm{H}_{2} \mathbf{L 6}$ with $\mathrm{Co}\left(\mathrm{ClO}_{4}\right)_{2}$, Dy(OTf $)_{3}$ and $\mathrm{Et}_{3} \mathrm{~N}$ in the molar ratio $2: 1: 1: 5$ in $\mathrm{MeOH}$ resulted, after 3 days, in approximately $82 \%$ yield, in dark-red shaped crystals formulated as $\left(\mathrm{Et}_{3} \mathrm{NH}\right)\left[\mathrm{Co}^{\mathrm{III}}(\mathbf{L 6})_{2}\right] \cdot 3 \mathrm{MeOH}[4 \cdot 3 \mathrm{MeOH}]$ (Fig. 2 left). Similarly, the reaction of $\mathrm{H}_{2} \mathbf{L 2 0}$ with $\mathrm{Co}\left(\mathrm{ClO}_{4}\right) \cdot 6 \mathrm{H}_{2} \mathrm{O}$, Dy $(\mathrm{OTf})_{3}$ and $\mathrm{Et}_{3} \mathrm{~N}$ in the molar ratio 1:1:1:3 in $\mathrm{MeOH}$ resulted, after 6 days, in approximately $82 \%$ yield dark, in red-shaped crystals formulated as $\left(\mathrm{Et}_{3} \mathrm{NH}\right)\left[\mathrm{Co}^{\mathrm{III}}(\mathbf{L 2 0})_{2}\right] \cdot 2 \mathrm{MeOH} \quad[5 \cdot 2 \mathrm{MeOH}]$ (Fig. 2, right). In the cases of 4 and 5, during crystallization, upon standing at room temperature, $\mathrm{Co}^{\mathrm{II}}$ is oxidized to $\mathrm{Co}^{\mathrm{III}}$. To target the isoskeletal 2,3M4-1 $\mathrm{Co}^{\text {II }}$ analogues, it is important to perform the synthesis and crystallization under inert atmosphere conditions.

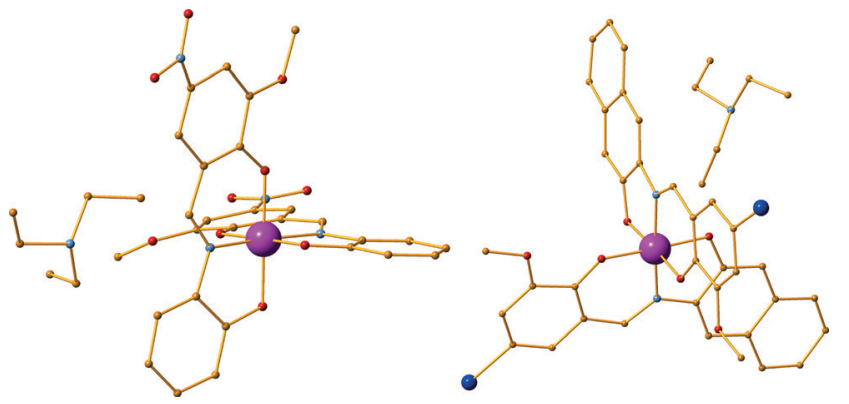

Fig. 2 (left) The crystal structure of compound 4. (right) The crystal structure of compound $\mathbf{5}$. Solvent molecules and $\mathrm{H}$-atoms are omitted for clarity. Colour code: Co (pink), N (light blue), O (red), C (orange), $\mathrm{Br}$ (blue).

\section{B) Solvent influence}

As anticipated, modification of the organic periphery of the parent organic ligand $\mathbf{H}_{2} \mathbf{L} \mathbf{1}$ drastically affects its solubility. However, when targeting the corresponding isoskeletal tetranuclear species, the use of a mixture of solvents, to enhance dissolution, results in the formation of undesired compounds. For example, the reaction of ligand $\mathrm{H}_{2} \mathrm{L14}$ with $\mathrm{Ni}\left(\mathrm{ClO}_{4}\right)_{2}, \mathrm{Dy}(\mathrm{OTf})_{3}$ and $\mathrm{Et}_{3} \mathrm{~N}$ in the molar ratio $2: 1: 1: 5$ in a mixture of $\mathrm{EtOH} / \mathrm{CH}_{2} \mathrm{Cl}_{2}$ results in the synthesis of a tetranuclear compound formulated as $\left[\mathrm{Ni}_{2}{ }_{2} \mathrm{Dy}{ }_{2}{ }_{2}(\mathbf{L 1 4})_{4}\right.$ (allyl-ovanillin $\left.)_{2}(\mathrm{EtOH})_{2}\right] \cdot 3 \mathrm{CH}_{2} \mathrm{Cl}_{2}\left[6 \cdot 3 \mathrm{CH}_{2} \mathrm{Cl}_{2}\right]$ (Fig. 3). The two allyl$o$-vanillin moieties are derived from the disassembly of $\mathbf{H}_{2} \mathbf{L} 14$ during the reaction. Interestingly, performing a similar reaction in solely DMF results in the formation of the desired $\quad\left[\mathrm{Ni}_{2}{ }_{2} \mathrm{Dy}^{\mathrm{III}}{ }_{2}(\mathrm{L14})_{4}(\mathrm{DMF})_{6}\right] \cdot 2\left(\mathrm{ClO}_{4}\right) \cdot 4 \mathrm{DMF} \quad[7 \cdot 4 \mathrm{DMF}]$ (Fig. 3). This observation was additionally proven by performing a reaction of ligand $\mathrm{H}_{2} \mathrm{L19}$ with $\mathrm{Ni}\left(\mathrm{ClO}_{4}\right)_{2} \cdot 6 \mathrm{H}_{2} \mathrm{O}$, Dy $(\mathrm{OTf})_{3}$ and $\mathrm{Et}_{3} \mathrm{~N}$ in the molar ratio $2: 1: 1: 5$ in a mixture of EtOH/ $\mathrm{CH}_{2} \mathrm{Cl}_{2}$, which resulted in the isolation of compound $\left[\mathrm{Ni}_{2}{ }_{2} \mathrm{Dy}{ }_{2}{ }_{2}(\mathrm{L19})_{4}(\text { bromo-o-vanillin })_{2}(\mathrm{EtOH})_{2}\right] \cdot 6 \mathrm{EtOH} \quad[8 \cdot 6 \mathrm{EtOH}]$ (Fig. 3). Moreover, utilizing a blend of EtOH/THF in the following reaction of $\mathrm{Ni}\left(\mathrm{ClO}_{4}\right)_{2} \cdot 6 \mathrm{H}_{2} \mathrm{O}$, Dy(OTf $)_{3}$ and $\mathrm{Et}_{3} \mathrm{~N}$ in the molar ratio $2: 1: 1: 5$ results in $\left[\mathrm{Ni}^{\mathrm{II}}{ }_{2} \mathrm{Dy}^{\mathrm{III}}{ }_{2}(\mathbf{L 1 5})_{4}\right.$ (allyl-ovanillin $\left.)_{2}(\mathrm{EtOH})_{2}\right] \cdot 2 \mathrm{THF} \cdot 2 \mathrm{EtOH}[$ 9-2THF-2EtOH] (Fig. 3). However, performing a similar reaction in DMF results in the formation of the desired compound $\left[\mathrm{Ni}^{\mathrm{II}}{ }_{2} \mathrm{Dy}{ }_{2}{ }_{2}(\mathbf{L 1 5})_{4}(\mathrm{DMF})_{2}\right]$ $\cdot 2\left(\mathrm{ClO}_{4}\right)[10]$ (Fig. 3). The aforementioned examples indicate that the use of a second solvent increases the chances of the formation of a by-product and thus the mixture of solvents may not correspond to an ideal synthetic protocol when targeting high purity compounds.

\section{C) Solvent concentration influence}

During our efforts to scale up the synthesis of compound $2,{ }^{57}$ we performed reactions with a lower amount of solvent (10 $\mathrm{ml}$ instead of $20 \mathrm{ml}$ ) or we tripled the amount of the reactants while retaining the same the molar ratio, but then a different product was obtained, formulated as $\left[\mathrm{Ni}_{2}{ }_{2} \mathrm{Dy}{ }_{2}{ }_{2}(\mathrm{L1})_{4}(\mathrm{EtOH})_{4}\left(\mathrm{H}_{2} \mathrm{O}\right)_{2}\right]\left(\mathrm{ClO}_{4}\right)_{2}$ (11) (Fig. 4). Two water molecules coordinate to $\mathrm{Ni}^{\mathrm{II}}$ centres in 11 , in contrast to two 

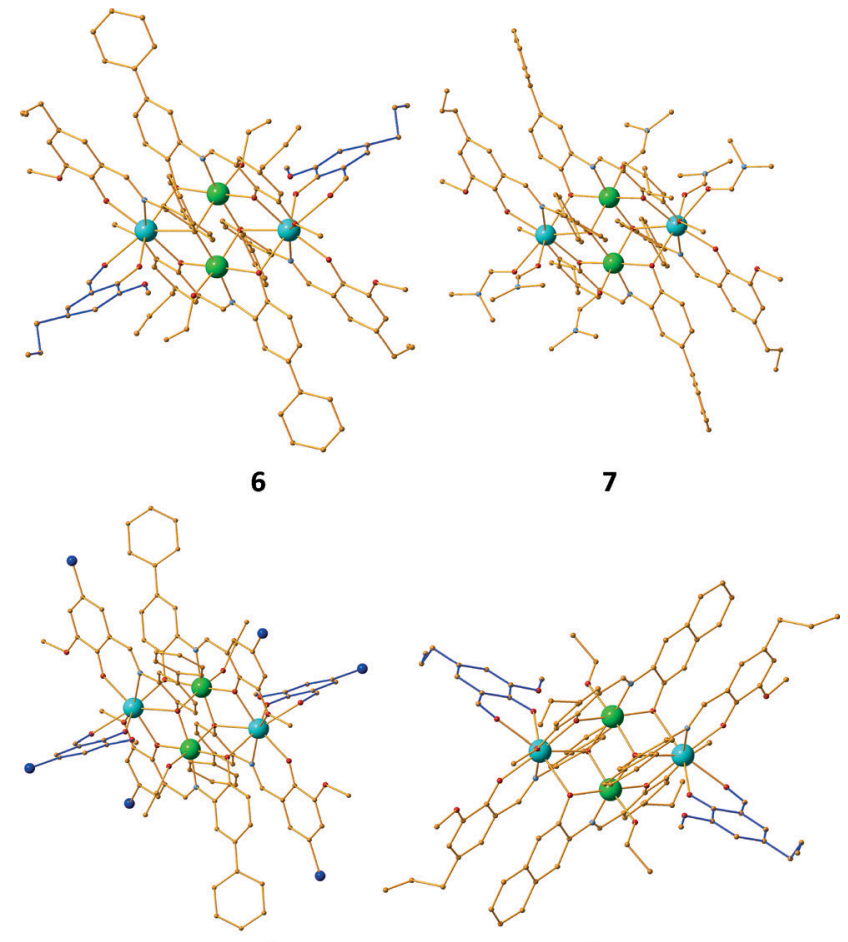

8

9

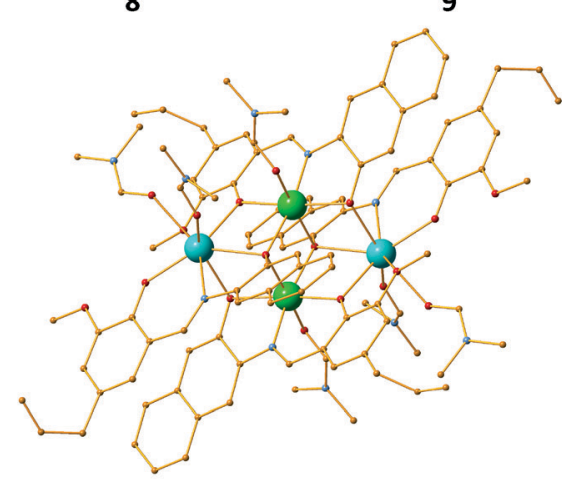

10

Fig. 3 The crystal structures of compounds 6-10. $\mathrm{H}$ atoms and solvents are omitted for clarity. The substituted $o$-vanillin moiety is indicated with blue colour. Colour code: Ni (light green), Dy (light blue), $\mathrm{N}$ (blue), O (red), C (orange), $\mathrm{Br}$ (blue).

ethanol molecules found in $2 .^{57}$ Moreover, when a similar scale up reaction is performed in a different solvent such as DMF, another compound is formed formulated as $\left[\mathrm{Ni}_{2}{ }_{2} \mathrm{Dy}_{2}{ }_{2}(\mathrm{L1})_{4}(\mathrm{DMF})_{6}\right]\left(\mathrm{OTf}_{3}\right)_{2} \cdot 2 \mathrm{DMF}$ (12.2DMF) (Fig. 4), instead of the expected perchlorate derivative. In addition, performing a concentrated reaction of $\mathrm{Ni}\left(\mathrm{ClO}_{4}\right) \cdot 6 \mathrm{H}_{2} \mathrm{O}$, Dy $(\mathrm{OTf})_{3}, \mathrm{Et}_{3} \mathrm{~N}$ and $\mathbf{H}_{2} \mathbf{L} 20$ in the molar ratio $1: 1: 2: 8$ resulted in a CC with the formula $\left[\mathrm{Ni}_{2}{ }_{2} \mathrm{Dy}^{\mathrm{III}}{ }_{2}(\mathrm{L20})_{4}(\mathrm{DMF})_{6}\right]$ $\left[\mathrm{Ni}_{2}{ }_{2} \mathrm{Dy}_{2}{ }_{2}(\mathrm{L20})_{4}(\mathrm{DMF})_{4}\left(\mathrm{H}_{2} \mathrm{O}\right)_{2}\right] \cdot 4\left(\mathrm{ClO}_{4}\right) \cdot 5 \mathrm{DMF}$ (13.5DMF) (Fig. 4).

\section{D) Molar ratio}

The reaction of $\mathrm{Ni}\left(\mathrm{ClO}_{4}\right)_{2} \cdot 6\left(\mathrm{H}_{2} \mathrm{O}\right)$, Dy $(\mathrm{OTf})_{3}$, and $\mathbf{H}_{2} \mathrm{L5}$ with $\mathrm{Et}_{3} \mathrm{~N}$ in $\mathrm{MeOH}$ in the molar ratio 1:1:2:5 resulted in the isolation of a tetranuclear cubane $\mathrm{Ni}_{4}$ formulated as

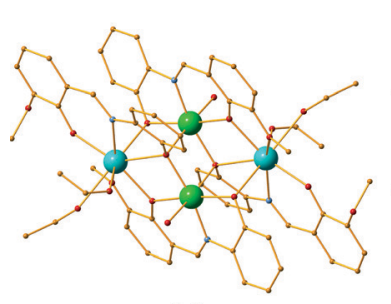

11

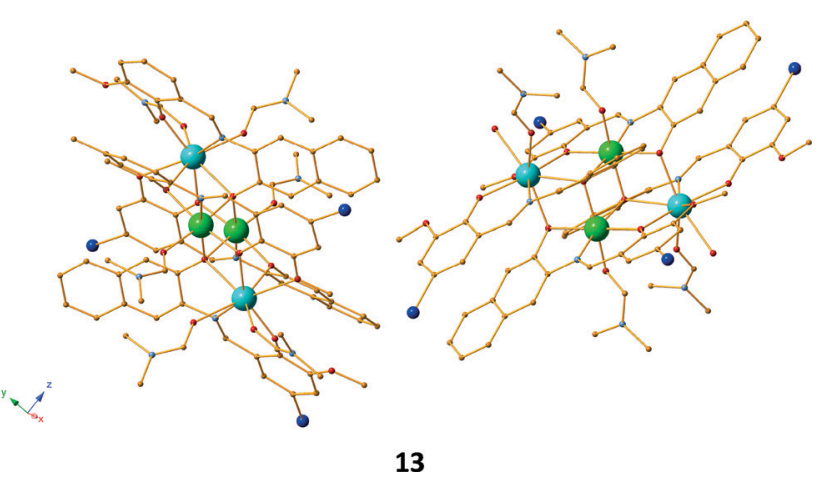

Fig. 4 The crystal structures of 11, 12 and 13. Colour code: Ni (light green), Dy (light blue), $\mathrm{N}$ (blue), $\mathrm{O}$ (red), C (orange), $\mathrm{Br}$ (blue), $\mathrm{F}$ (green) $S$ (yellow).

$\left[\mathrm{Ni}^{\mathrm{II}}{ }_{4}(\mathbf{L 5})_{4}(\mathrm{MeOH})_{4}\right] \cdot 6 \mathrm{MeOH}(\mathbf{1 4} \cdot 6 \mathrm{MeOH})$ which is isoskeletal to the tetranuclear cubic $\mathrm{Ni}_{4} \mathrm{CC}$ formed by the $\mathrm{H}_{2} \mathbf{L 1}$ ligand, reported recently. ${ }^{54}$ However, performing the same reaction in $\mathrm{EtOH}$ results in the isolation of the targeted isoskeletal tetranuclear $\left[\mathrm{Ni}^{\mathrm{II}}{ }_{2} \mathrm{Dy}{ }_{2}^{\mathrm{III}}{ }_{2}(\mathrm{L5})_{4}(\mathrm{EtOH})_{6}\right] \cdot 2\left(\mathrm{ClO}_{4}\right) \cdot 4 \mathrm{EtOH}(\mathbf{1 5} \cdot 4 \mathrm{EtOH})$ (Fig. 5).

\section{E) Solvent diffusion crystallization}

In our effort to obtain the targeted tetranuclear $\mathrm{Ni}_{2}^{\mathrm{II}}{ }_{2} \mathrm{Dy}{ }_{2}{ }_{2}$ analogues with $\mathbf{H}_{2} \mathbf{L} 4$ as a ligand via the diffusion crystallization technique, a compound formulated as $\left[\mathrm{Ni}_{2}{ }_{2}{ }^{\mathrm{Dy}}{ }_{2}{ }_{2}(\mathrm{~L} 4)_{4}(\mathrm{DMF})_{6}\right]$ $\cdot 2\left(\mathrm{ClO}_{4}\right) \cdot 2 \mathrm{Et}_{2} \mathrm{O}\left(\mathbf{1 6} \cdot 2 \mathrm{Et}_{2} \mathrm{O}\right)$ (Fig. 6, left) which contains two ether molecules as lattice solvents, was isolated. Upon standing at room temperature, ${ }^{71-74}$ compound 16 immediately loses its crystallinity.

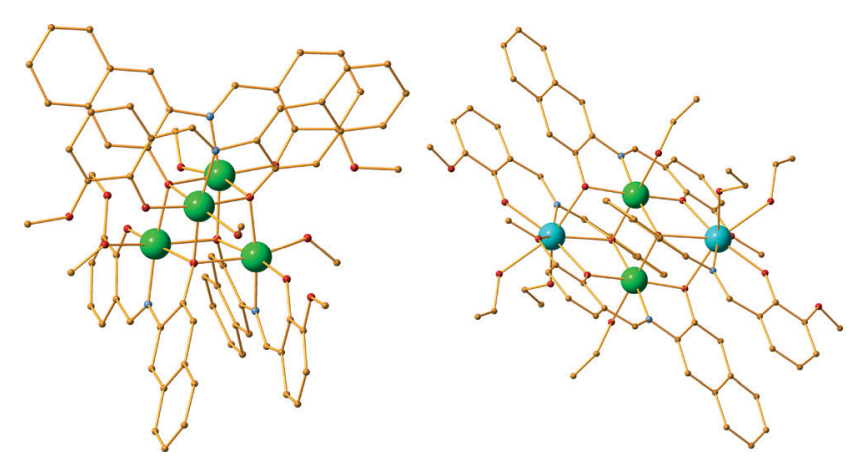

Fig. 5 The crystal structures of compounds 14 (left) and 15 (right). Colour code: Ni (light green), Dy (light blue), N (blue), O (red), C (orange). 


\section{F) Co-ligand introduction}

To identify the possibility of introducing a monocarboxylate group as a co-ligand on the periphery of the 2,3M4-1 motif, we performed a pilot reaction with $\mathbf{H}_{2} \mathbf{L 1}, \mathrm{Ni}(\mathrm{OAc})_{2} \cdot 4\left(\mathrm{H}_{2} \mathrm{O}\right)$, $\mathrm{Dy}(\mathrm{OTf})_{3}$ and $\mathrm{Et}_{3} \mathrm{~N}$ in the molar ratio $2: 1: 1: 2$ in $\mathrm{MeOH}$ that resulted in the isolation of a compound formulated as $\left[\mathrm{Ni}_{2}{ }_{2} \mathrm{Dy}{ }_{2}(\mathrm{L1})_{4}(\mathrm{OAc})_{2}(\mathrm{MeOH})_{2}\right] \cdot 2 \mathrm{MeOH}(\mathbf{1 7} \cdot 2 \mathrm{MeOH})$ (Fig. 6, right). Each acetate group bridges the Ni and Dy centres, which is in contrast to the $\mathrm{NO}_{3}$ analogues that prefer to chelate to the $\mathrm{Ln}$ centres. $^{46,47}$

Employment of the bulky co-ligands M1 and M2 along with ligand $\mathrm{H}_{2} \mathrm{L12}, \mathrm{Co}\left(\mathrm{ClO}_{4}\right)_{2} \cdot 6 \mathrm{H}_{2} \mathrm{O}$ and $\mathrm{Dy}(\mathrm{OTf})_{3}$ in the molar ratio of $2: 1: 1: 5$ in $N, N^{\prime}$-DMF as solvent results in the isolation of two compounds formulated as $\left[\mathrm{Co}_{2}{ }_{2} \mathrm{Dy}^{\mathrm{III}}{ }_{2}(\mathbf{L 1 2})_{4}(\mathbf{M 1})_{2}(\mathrm{DMF})_{2}\right]$ (18) and $\left[\mathrm{Co}_{2}{ }_{2} \mathrm{Dy}_{2}{ }_{2}(\mathrm{L12})_{4}(\mathrm{M} 2)_{2}(\mathrm{DMF})_{2}\right] \cdot 2 \mathrm{DMF} \quad(\mathbf{1 9} \cdot 2 \mathrm{DMF})$, respectively (Fig. 7).

However, our effort to obtain the isoskeletal compound to $18 \mathrm{Co}_{2}^{\mathrm{II}}{ }_{2} \mathrm{Dy}{ }_{2}$ III compound along with ligand $\mathrm{H}_{2} \mathrm{~L} 2$ instead of $\mathrm{H}_{2} \mathbf{L 1 2}$ we performed a similar reaction which resulted in red plate crystals formulated as $\left[\mathrm{Dy}^{\mathrm{III}}(\mathrm{M1})_{3}(\mathrm{DMF})_{2}\right](20)$ (Fig. 8). Compound 20 is a one-dimensional (1D) coordination polymer and can be considered as a polymorph to the recently reported compound. ${ }^{75}$

Finally, the diffusion of $\mathrm{Et}_{2} \mathrm{O}$ to a concentrated reaction of ligand $\mathrm{H}_{2} \mathrm{L5}$ along with $\mathrm{Ni}\left(\mathrm{ClO}_{4}\right) \cdot 6 \mathrm{H}_{2} \mathrm{O}, \mathrm{Dy}(\mathrm{OTf})_{3}, \mathrm{M} 1$ and $\mathrm{Et}_{3} \mathrm{~N}$ in DMF results in the formation of a compound formulated as $\left[\mathrm{Ni}_{2}{ }_{2} \mathrm{Dy}_{2}{ }_{2}(\mathrm{OH})(\mathrm{L} 5)_{3}(\mathrm{M1})_{3}(\mathrm{DMF})_{2}\right] \cdot 1.5 \mathrm{DMF} \cdot \mathrm{Et}_{2} \mathrm{O} \quad(21$ -1.5DMF. $\mathrm{Et}_{2} \mathrm{O}$ ) which possesses the 2,3M4-1 topology. Surprisingly, only three organic ligands are involved in the aggregation in contrast to the four ligands used in compounds 6-19. The skeleton of $\mathbf{2 1}$ is further supported by the presence of a hydroxyl $\mu_{3}-\mathrm{OH}$ group. Also, one $\mathrm{Et}_{2} \mathrm{O}$ molecule is trapped in the lattice (Fig. 9).

\section{Solution studies}

To further confirm the identity of compounds 7, 10 and 16 in solution, we performed an electrospray ionization mass (ESI-MS) spectrometry study. For 7, we observed three peaks in the MS (positive-ion mode) at $\mathrm{m} / z$ 1009.2113, 972.1730 and 936.1485
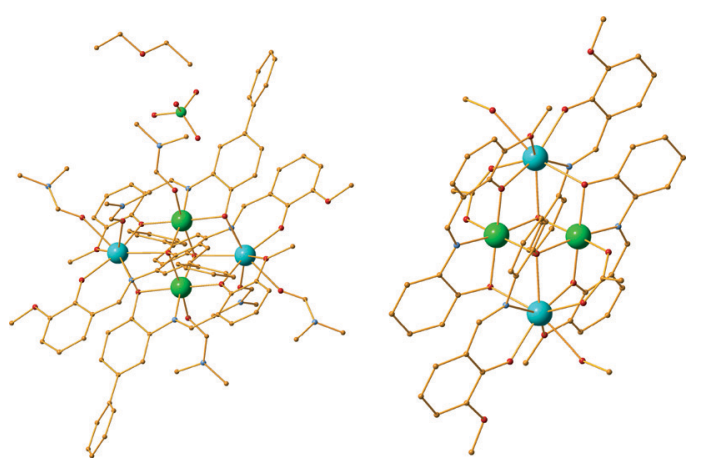

Fig. 6 The crystal structures of compound 16 (left) and 17 (right). Colour code: Ni (light green), Dy (light blue), N (blue), O (red), Cl (light green).
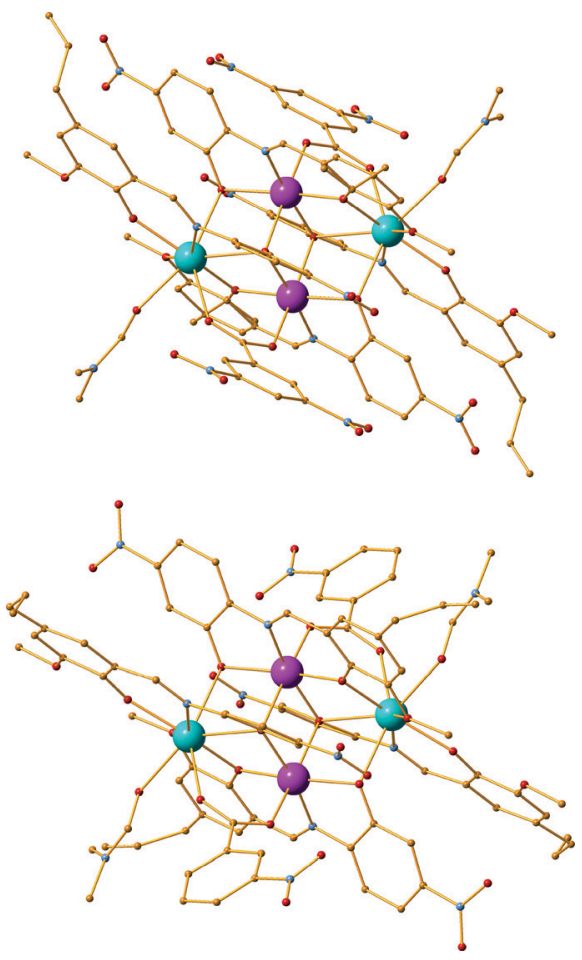

Fig. 7 The crystal structures of compounds 18 (upper) and 19 (lower). Colour code: Co (pink), Dy (light blue), N (blue), O (red), C (orange).

which correspond perfectly to three dicationic fragments, $\left[\mathrm{Ni}_{2}{ }_{2} \mathrm{Dy}{ }_{2}{ }_{2}(\mathbf{L 1 4})_{4}(\mathrm{DMF})_{2}\right]^{2+}, \quad\left[\mathrm{Ni}_{2}{ }_{2} \mathrm{Dy}^{\mathrm{III}}{ }_{2}(\mathrm{L14})_{4}(\mathrm{DMF})\right]^{2+}$ and $\left[\mathrm{Ni}_{2}{ }_{2} \mathrm{Dy}_{2}^{\mathrm{III}}{ }_{2}(\mathbf{L 1 4})_{4}\right]^{2+}$, respectively (see Fig. S1 ESI $\dagger$ ). Similarly, for 10, the peaks at $m / z 1742.2549,876.6074,840.0702$ and 803.067 correspond to $\left[\mathrm{Ni}_{2}{ }_{2} \mathrm{Dy}^{\mathrm{III}}{ }_{2}(\mathbf{L 1 5})_{4}(\mathrm{MeOH})\right]^{+}, \quad\left[\mathrm{Ni}_{2}{ }_{2} \mathrm{Dy}_{2}{ }_{2}{ }_{2}(\mathbf{L 1 5})_{4}{ }^{-}\right.$ $\left.(\mathrm{DMF})_{2}\right]^{2+}, \quad\left[\mathrm{Ni}_{2}{ }_{2} \mathrm{Dy}^{\mathrm{III}}{ }_{2}(\mathbf{L 1 5})_{4}(\mathrm{DMF})\right]^{2+}$, and $\left[\mathrm{Ni}_{2}{ }_{2} \mathrm{Dy}^{\mathrm{III}}{ }_{2}(\mathbf{L 1 5})_{4}\right]^{2+}$ fragments (see Fig. S2 $\dagger$ ), respectively. For compound 16, the following four $m / z$ 1847.228, 929.1356, 892.1121 and 855.5781 peaks correspond to $\left[\mathrm{Ni}^{\mathrm{II}}{ }_{2} \mathrm{Dy}{ }_{2}{ }_{2}(\mathbf{L 4})_{4}(\mathrm{MeOH})\right]^{+},\left[\mathrm{Ni}^{\mathrm{II}}{ }_{2} \mathrm{Dy}{ }_{2}{ }_{2}(\mathbf{L 4})_{4}(\mathrm{DMF})_{2}\right]^{2+}$, $\left[\mathrm{Ni}_{2}{ }_{2} \mathrm{Dy}{ }_{2}{ }_{2}(\mathbf{L 4})_{4}(\mathrm{DMF})\right]^{2+}$ and $\left[\mathrm{Ni}_{2}{ }_{2}{ }^{\mathrm{Dy}}{ }_{2}{ }_{2}(\mathbf{L 4})_{4}\right]^{2+}$ fragments (see Fig. S3†), respectively. However, all the efforts to obtain similar ESI-MS spectra for compounds 18 and 19, which contain a co-ligand, were not successful.

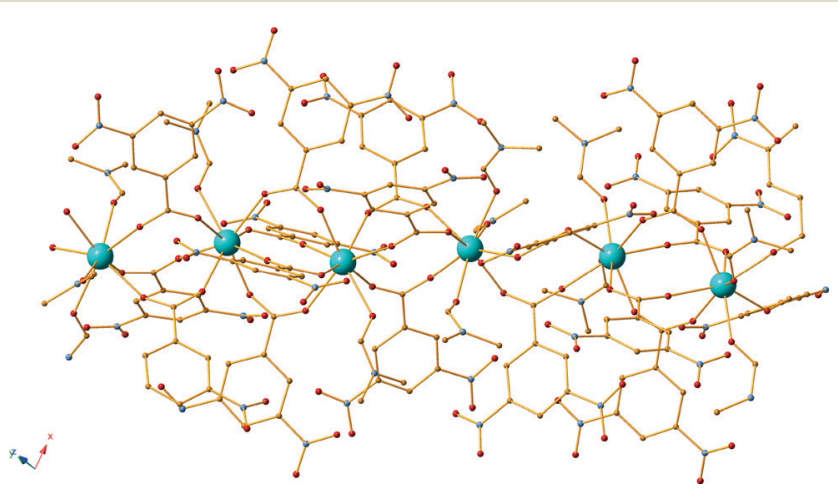

Fig. 8 The crystal structure of compound 20. Colour code: Dy (light blue), $\mathrm{N}$ (blue), $\mathrm{O}$ (red), C (orange). 


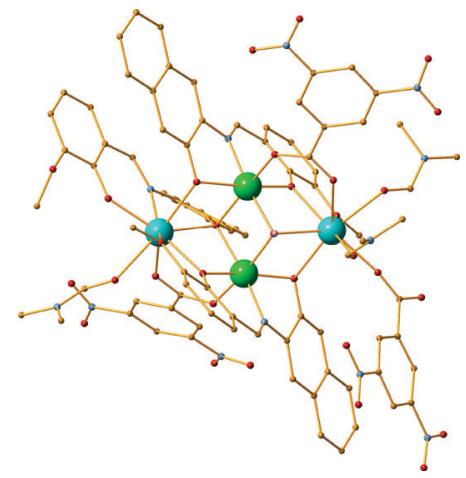

Fig. 9 The crystal structure of compound 21. Colour code: Ni (light green), Dy (light blue), N (blue), O (red), C (orange), H (white).

\section{Theoretical studies}

To gain further insight into the tuning and modulation of, inter alia, the catalytic activities of the tetranuclear CCs, computational studies were carried out. Specifically, the influence of the organic ligands on the electronic properties of the metals was studied. The reason for this study is that the 'activity' of the ligands may be tuned by employing diverse functional groups at specific sites/positions. In order to do this, quantitative and qualitative metrics of the functional group effects were established and in parallel several congeners of the ligands were examined; more so, several model systems of the polynuclear coordination clusters were used. With respect to Scheme 2 (see text) concerning the numbering, the following tables (Tables 2-5) indicate the model systems studied. Fig. 10 shows the visualization of the mapped molecular electrostatic potential in ligands L1m to $\mathrm{L} 12 \mathrm{~m}$, as in the usual molecular electrostatic potential (MEP) rendering, with the blue zones depicting the 'positively' charged zones, while the red zones the 'negatively charged zones'.

One way to assess the effect of the electron-withdrawing groups on the Schiff base is to qualitatively render the MEP mapped onto the van der Waals surface. Indeed, the nature of the $\mathrm{R}$ groups has a profound effect on the surface charge of the base on its 'inner cove' - that is, the $\mathrm{O}-\mathrm{O}-\mathrm{N}-\mathrm{O}$ core

Table 2 Recapitulative table of the model ligands used

\begin{tabular}{lcll}
\hline $\mathrm{L}$ & $\mathrm{R}_{1}$ & $\mathrm{R}_{2}$ & $\mathrm{R}_{3}$ \\
\hline $\mathrm{L} 1 \mathrm{~m}$ & $\mathrm{H}$ & $\mathrm{H}$ & $\mathrm{H}$ \\
$\mathrm{L} 2 \mathrm{~m}$ & $\mathrm{OMe}_{\mathrm{CM}}$ & $\mathrm{H}$ & $\mathrm{H}$ \\
$\mathrm{L} 3 \mathrm{~m}$ & $\mathrm{~N}\left(\mathrm{CH}_{2} \mathrm{CH}_{3}\right)_{2}$ & $\mathrm{H}$ & $\mathrm{H}$ \\
$\mathrm{L} 4 \mathrm{~m}$ & $\mathrm{~F}$ & $\mathrm{H}$ & $\mathrm{H}$ \\
$\mathrm{L} 5 \mathrm{~m}$ & $\mathrm{H}$ & $\mathrm{H}$ & $\mathrm{NO}_{2}$ \\
$\mathrm{~L} 6 \mathrm{~m}$ & $\mathrm{CH}_{2} \mathrm{CH}=\mathrm{CH}_{2}$ & $\mathrm{H}$ & $\mathrm{NO}_{2}$ \\
$\mathrm{~L} 7 \mathrm{~m}^{1}$ & $\mathrm{NO}_{2}$ & $\mathrm{H}$ & $\mathrm{H}$ \\
$\mathrm{L} 8 \mathrm{~m}$ & $\mathrm{NO}_{2}$ & $\mathrm{H}$ & $\mathrm{H}$ \\
$\mathrm{L} 9 \mathrm{~m}$ & $\mathrm{H}$ & $\mathrm{Cl}$ & $\mathrm{NO}_{2}$ \\
$\mathrm{~L} 10 \mathrm{~m}$ & $\mathrm{Br}_{\mathrm{L} 11 \mathrm{~m}}$ & $\mathrm{H}$ & $\mathrm{NO}_{2}$ \\
$\mathrm{~L} 12 \mathrm{~m}$ & $\mathrm{NO}_{2}$ & $\mathrm{H}$ & $\mathrm{NO}_{2}$ \\
$\mathrm{~L}$ & $\mathrm{NO}$ & $\mathrm{Cl}$ & $\mathrm{NO}_{2}$
\end{tabular}

L7: an additional $\mathrm{NO}_{2}$ is substituted at the ortho position adjacent to $\mathrm{R}_{2}$.
Table 3 Recapitulative table of the co-ligands used

\begin{tabular}{llll}
\hline coL & $\mathrm{R}_{4}$ & $\mathrm{R}_{5}$ & $\mathrm{R}_{6}$ \\
\hline $\operatorname{coL} 1 \mathrm{~m}$ & $\mathrm{H}$ & $\mathrm{H}$ & $\mathrm{H}$ \\
$\operatorname{coL} 2 \mathrm{~m}$ & $\mathrm{H}$ & $\mathrm{F}$ & $\mathrm{H}$ \\
$\operatorname{coL} 3 \mathrm{~m}$ & $\mathrm{NO}_{2}$ & $\mathrm{H}$ & $\mathrm{NO}_{2}$
\end{tabular}

pattern that directly interacts with the metals. Fig. 10 and Table 5 qualitatively illustrate this idea. Unsurprisingly, the results show that the charge distribution along the cove can indeed be modulated upon modification of the groups.

In the gas phase, in their most stable geometrical configuration, the most 'simple' functionalization, i.e. having $\mathrm{R}_{1}=$ $\mathbf{R}_{2}=\mathbf{R}_{3}=\mathrm{H}$ turns out to confer the highest negative charge accumulation on the ligand 'anchor' points, the least being with $\mathrm{R}_{1}=\mathrm{NO}_{2}, \mathrm{R}_{2}=\mathrm{Cl}, \mathrm{R}_{3}=\mathrm{NO}_{2}$. Interestingly, for a given $\mathrm{R}_{1}$, changing $R_{3}$ has a profound effect on the charge distribution as can be illustrated by considering $\mathrm{L} 1 \mathrm{~m}$ and $\mathrm{L} 5 \mathrm{~m}$. On the other hand, for a given $R_{3}$, changing $R_{1}$ does not have a noticeable altering effect, as shown for example by $\mathrm{L} 5 \mathrm{~m}$ versus $\mathrm{L} 10 \mathrm{~m}$ and $\mathrm{L} 1 \mathrm{~m}$ versus $\mathrm{L} 2 \mathrm{~m}$. More crucially, the conformation of the ligand, although not surprisingly, ultimately determines the extent, nature and motifs of the interaction between the metal-interacting side of the ligands and the metals (see Fig. 11). Indeed, single point (sp) calculations on L6m in its ligand-bound geometry exhibits a different charge distribution signature with respect to that of its gas-phase optimized structure (gp). The geometries differ by having the nitrogen-bound aryl group (ring 2) rotated clockwise (gp) or counter clockwise (sp) around the $\mathrm{N}-\mathrm{C}(\operatorname{aryl})$ bond. This observation can be rationalized when one considers the frontier molecular orbitals (MO).

Indeed, inspection of the LUMO-HOMO-2 of L6m (sp) indicates that the molecular orbitals (MO) are mainly consisted of $\pi$ networks running throughout the whole molecule; even

Table 4 Recapitulative table of the models used

\begin{tabular}{cccccc}
\hline Model & M1 & M2 & L & coL & S \\
\hline m1 11 & Zn & Y & L1m & coL2m & $\left(\mathrm{CH}_{3}\right)_{2} \mathrm{NCOH}$ \\
m2 11a & Ni & Y & L1m & coL2m & $\left(\mathrm{CH}_{3}\right)_{2} \mathrm{NCOH}$ \\
m3 12 & $\mathrm{Zn}$ & $\mathrm{Y}$ & $\mathrm{L} 5 \mathrm{~m}$ & MeOH & $\mathrm{NO}_{3}$ \\
m4 12a & $\mathrm{Ni}$ & $\mathrm{Y}$ & $\mathrm{L} 5 \mathrm{~m}$ & MeOH & $\mathrm{NO}_{3}$ \\
m5 13 & $\mathrm{Zn}$ & $\mathrm{Y}$ & $\mathrm{L} 1 \mathrm{~m}$ & EtOH & - \\
m6 14 & $\mathrm{Zn}$ & $\mathrm{Y}$ & $\mathrm{L} 6 \mathrm{~m}$ & coL3m & $\mathrm{S} 1 \mathrm{~m}$ \\
m7 14b & $\mathrm{Zn}$ & $\mathrm{Y}$ & $\mathrm{L} 1 \mathrm{~m}$ & coL3m & $\mathrm{S} 1 \mathrm{~m}$
\end{tabular}

Table 5 Mulliken charges

\begin{tabular}{llllll}
\hline Model & $q(\mathrm{M} 1)$ & $q(\mathrm{M} 2)$ & $q(\mathrm{O} 1)$ & $q(\mathrm{~N})$ & $q(\mathrm{O} 2)$ \\
\hline m1 11 & 0.79 & 1.49 & -0.64 & -0.20 & -0.61 \\
m2 11a & 0.53 & 1.49 & -0.61 & -0.16 & -0.59 \\
m3 12 & 0.93 & 1.34 & -0.55 & -0.26 & -0.73 \\
m4 12a & 0.69 & 1.36 & -0.62 & -0.17 & -0.58 \\
m5 13 & 0.86 & 1.32 & -0.56 & -0.30 & -0.73 \\
m6 14 & 0.85 & 1.56 & -0.55 & -0.27 & -0.70 \\
m7 14b & 0.85 & 1.55 & -0.56 & -0.27 & -0.71
\end{tabular}



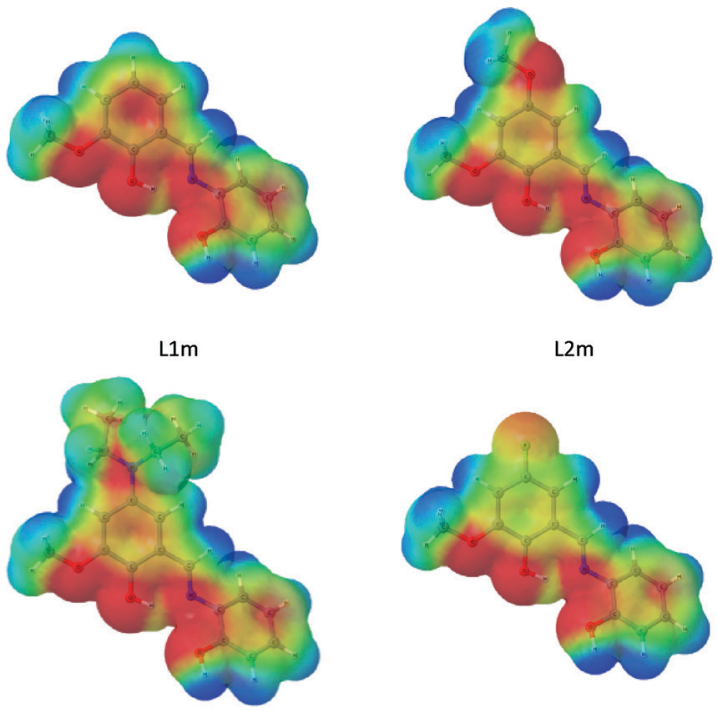

$\mathrm{LBm}$

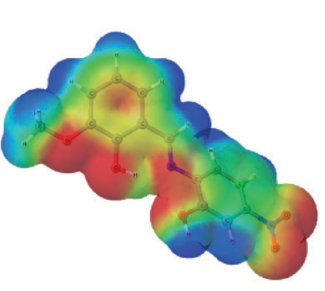

$\mathrm{L} 5 \mathrm{~m}$

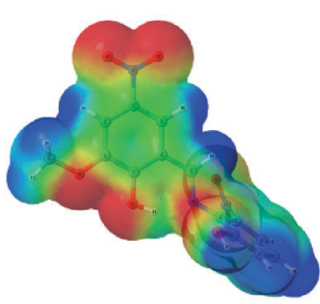

$\mathrm{L} 7 \mathrm{~m}$

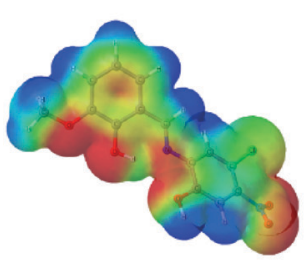

$\mathrm{L9m}$

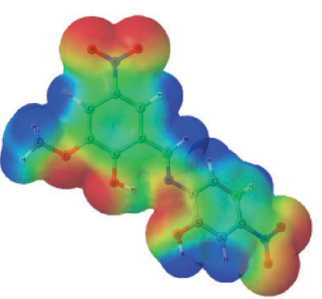

$\mathrm{L} 11 \mathrm{~m}$

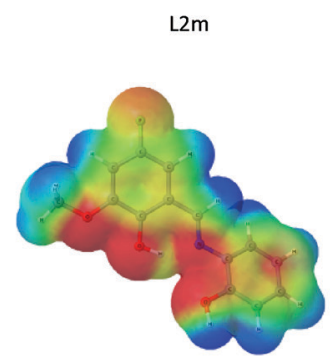

$\mathrm{L} 4 \mathrm{~m}$

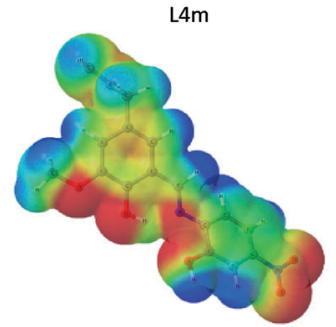

$\mathrm{L} 6 \mathrm{~m}$

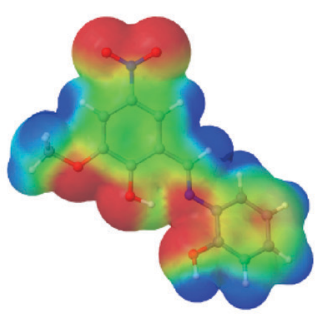

L8m

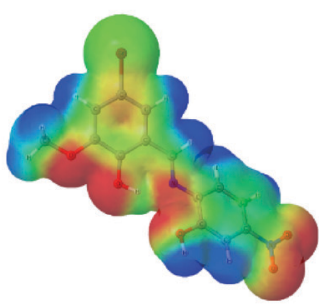

$\mathrm{L} 10 \mathrm{~m}$

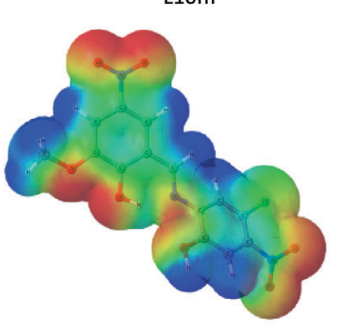

$\mathrm{L} 12 \mathrm{~m}$

Fig. 10 Rendition of the molecular electrostatic potential (MEP) of the model ligands.
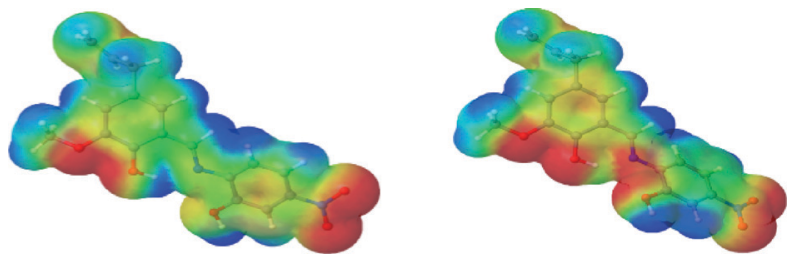

Fig. 11 Rendition of the molecular electrostatic potential (MEP) of $\mathrm{L} 6 \mathrm{~m}$ in its ligand-bound (left) and in its free conformation (right).

more remarkable is the low mixing of atomic p orbitals perpendicular to the molecular plane defined by ring 1 (the aryl containing R1) and the N-centered p orbital that is parallel to this plane (see Fig. 12). This very orientation of the p orbital should also be responsible for the dependence of the cove charge distribution on the orientation of the hydrogens on the $\mathrm{OH}$ functions on both rings (data not shown).

In terms of partial atomic charge, within the Mulliken partitioning scheme, it can be noted that there are indeed variations in values on the metals, on the two oxygen and the nitrogen atoms (see Table 5) depending on the makeup of the ligand. Close examination suggests that, in terms of partial charges, both M2 (Table 4) and O1 (the phenolic oxygen atom of the $o$-vanillin moiety) are spectator elements and the value of their partial charge does not depend on that of the other atoms. However, an interdependence of the values of partial charge on $\mathrm{N}, \mathrm{O} 2$ (the phenolic oxygen atom of the aminophenol moiety) and M1 can be found. The largest of such variations occurs for metal M1 and is observed between model $\mathrm{m} 2$ 11a and model $\mathrm{m} 312$. These results are perfectly in line with that of the charge distribution being dependent on the orientation of ring 2 .

The above results clearly show the richness of the chemistry of the present coordination clusters: the nature of metal M1 and the identity of the R groups in the ligands play preponderant roles in both the tuning and control of the

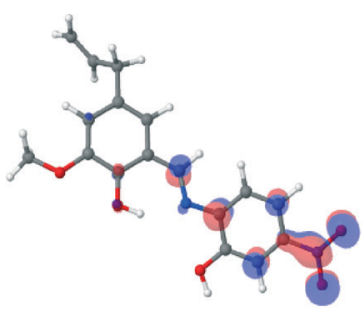

LUMO

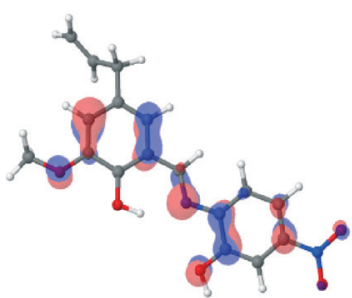

HOMO-1

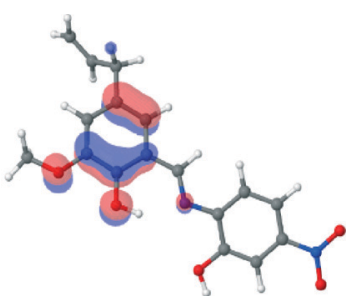

HOMO

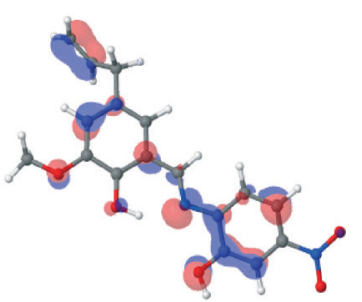

HOMO-2
Fig. 12 Frontier orbitals of $\mathrm{L} 6 \mathrm{~m}$ (sp). 
behaviour of the clusters. With the trends and rationale hereby demonstrated, it should be possible in future work to better modulate the activity of the clusters through tuning of the electronic structure and control of structural constraints.

\section{Conclusions}

In this work we present the synthesis of nineteen new substituted Schiff base organic ligands and eighteen new CCs. Adopting the MOF isoreticular concept, we introduce herein the term "isoskeletal" which ideally describes the structural and topological similarities found in compounds 6-13, 15-19 and 21. Microwave synthesis has proven to be very efficient for the synthesis of the substituted Schiff base ligands. ${ }^{76}$ Targeting the synthesis of such isoskeletal species, it is shown that several parameters must be taken into account. We do show here that a slight change in the synthetic procedure drastically affects the formula of the desired compound. However, the usage of different lanthanide sources and the lanthanide contraction are two parameters that have not been taken into account in this study and are anticipated to have a major impact on the shape, nuclearity and formula of the final product. The possibility of producing isoskeletal species and exchanging the $3 \mathrm{~d}$ and/or the $4 \mathrm{f}$ elements with diamagnetic elements such as $\mathrm{Zn}^{\mathrm{II}}$ or $\mathrm{Y}^{\mathrm{III}}$ gives the opportunity to further study the targeted molecules in the solid and/ or solution state with additional spectroscopic techniques such as NMR $\left({ }^{1} \mathrm{H},{ }^{13} \mathrm{C},{ }^{89} \mathrm{Y}\right)$ or EPR for the $\mathrm{Gd}^{\mathrm{III}}$ species. For the present study, ESI-MS studies of compounds 7, 10 and 16 are indicative that the targeted species remain intact in solution. However, upon introduction of co-ligands the targeted CCs become insoluble in alcoholic solvents. Computational studies showcase how the likely activity of the CCs can be tuned and modulated, and suggest ways on achieving this, hence demonstrating the richness of the chemistry of the hereby reported constructs. Our future efforts will be focused on further exploring the coordination chemistry of these species as well on performing such systematic studies involving other organic ligands, aiming to isolate molecules with better magnetic, catalytic or fluorescence properties.

\section{Experimental}

\section{Materials}

Chemicals (reagent grade) were purchased from Sigma Aldrich and Alfa Aesar. Detailed synthesis and characterization of the HL ligand is described in the ESI. $\dagger$ All experiments were performed under aerobic conditions using materials and solvents as received. Safety note: perchlorate salts are potentially explosive; such compounds should be used in small quantities and handled with caution and utmost care at all times.

\section{Synthesis}

Detailed synthetic protocols can be found in the ESI.† Powder XRD spectra of compounds 4-21 were not recorded, due to the fact that these molecules can be considered as unexpected reaction products. Elemental analysis results of selected samples $(7,10,11,13$ and 16) are reported in the ESI. $\dagger$

\section{Instrumentation}

IR spectra of the samples were recorded over the range of 4000-650 $\mathrm{cm}^{-1}$ on a Perkin Elmer Spectrum One FT-IR spectrometer fitted with a UATR polarization accessory.

\section{Computational details}

Energy minimization on strategically designed model compounds (see Results and discussion) was conducted within the Kohn-Sham Density Functional Theory (DFT) approach at the $\mathrm{B} 3 \mathrm{LYP} / \mathrm{SDD}$ and $\mathrm{B} 3 \mathrm{LYP} / 6-311 \mathrm{G}^{*}$ levels. $^{77-87}$ Calculations were carried using the Gaussian09 (ref. 88) software. The Jmol program was used for visualization purposes. ${ }^{89}$

\section{X-ray crystallography}

Data for $\mathrm{H}_{2} \mathrm{L3}, \mathrm{H}_{2} \mathrm{L19}, 5-8,10-12,15-17$ and 21 were collected ( $\omega$-scans) at the University of Sussex using an Agilent Xcalibur Eos Gemini Ultra diffractometer with a CCD plate detector under a flow of nitrogen gas at 173(2) K using Mo K $\alpha$ radiation $(\lambda=0.71073 \AA$ ) . CRYSALIS CCD and RED software were used respectively for data collection and processing. Reflection intensities were corrected for absorption by the multi-scan method. Data for 4, 9, 13, 14, 18-20 were collected at the National Crystallography Service, University of Southampton. $^{90}$ All structures were determined using Olex2, ${ }^{91}$ solved using either Superflip ${ }^{92}$ or SHELXT $^{93,94}$ and refined with SHELXL-2014. ${ }^{95}$ All non-H atoms were refined with anisotropic thermal parameters, and H-atoms were introduced at calculated positions and allowed to ride on their carrier atoms. Geometric/crystallographic calculations were performed using PLATON, ${ }^{96}$ Olex $2,{ }^{91}$ and WINGX ${ }^{93}$ packages; graphics were prepared with Crystal Maker. ${ }^{97}$ For compounds 8, 9 and 14 the SQUEEZE process was applied. ${ }^{98}$ Each of the crystal structures has been deposited at the CCDC with reference numbers 1406218-1406237.

\section{Acknowledgements}

We thank the EPSRC (UK) for funding (grant number EP/ M023834/1), the University of Sussex for offering a PhD position to K. G., the EPSRC UK National Crystallography Service at the University of Southampton for the collection of the crystallographic data for compounds $4,9,13,14,18-20$, the Research Development Funding from the University of Sussex (V. N. D.) and Profs. Vladislav Blatov and Davide Proserpio for helpful scientific discussions.

\section{Notes and references}

1 L. Cronin and J. Fielden, in Coordination Clusters in Encyclopedia of Supramolecular Chemistry, Taylor and Francis, London, 2007, Taylor \& Francis, 2007, pp. 1-10. 
2 G. E. Kostakis, A. M. Ako and A. K. Powell, Chem. Soc. Rev., 2010, 39, 2238-2271.

3 Z.-M. Zhang, S. Yao, Y.-G. Li, R. Clérac, Y. Lu, Z.-M. Su and E.-B. Wang, J. Am. Chem. Soc., 2009, 131, 14600-14601.

4 X.-J. Kong, Y.-P. Ren, W.-X. Chen, L.-S. Long, Z. Zheng, R.-B. Huang and L.-S. Zheng, Angew. Chem., Int. Ed., 2008, 47, 2398-2401.

5 A. A. Athanasopoulou, M. Pilkington, C. P. Raptopoulou, A. Escuer and T. C. Stamatatos, Chem. Commun., 2014, 50, 14942-14945.

6 C.-M. Liu, D.-Q. Zhang and D.-B. Zhu, Dalton Trans., 2010, 39, 11325-11328.

7 J.-B. Peng, X.-J. Kong, Q.-C. Zhang, M. Orendáč, J. Prokleška, Y.-P. Ren, L.-S. Long, Z. Zheng and L.-S. Zheng, J. Am. Chem. Soc., 2014, 136, 17938-17941.

8 Z. M. Zhang, L. Y. Pan, W. Q. Lin, J. D. Leng, F. S. Guo, Y. C. Chen, J. L. Liu and M. L. Tong, Chem. Commun., 2013, 49, 8081-8083.

9 L. Zhao, J. Wu, S. Xue and J. Tang, Chem. - Asian J., 2012, 7, 2419-2423.

10 M. Wu, F. Jiang, D. Yuan, J. Pang, J. Qian, S. A. Al-Thabaiti and M. Hong, Chem. Commun., 2014, 50, 1113-1115.

11 D. D'Alessio, A. N. Sobolev, B. W. Skelton, R. O. Fuller, R. C. Woodward, N. A. Lengkeek, B. H. Fraser, M. Massi and M. I. Ogden, J. Am. Chem. Soc., 2014, 136, 15122-15125.

12 E. N. Chygorin, V. N. Kokozay, I. V. Omelchenko, O. V. Shishkin, J. Titiš, R. Boča and D. S. Nesterov, Dalton Trans., 2015, 44, 10918-10922.

13 D. S. Nesterov, E. N. Chygorin, V. N. Kokozay, V. V. Bon, R. Boča, Y. N. Kozlov, L. S. Shul'pina, J. Jezierska, A. Ozarowski, A. J. L. Pombeiro and G. B. Shul'pin, Inorg. Chem., 2012, 51, 9110-9122.

14 Z. Ma, L. Wei, E. C. B. A. Alegria, L. M. D. R. S. Martins, M. F. C. Guedes da Silva and A. J. L. Pombeiro, Dalton Trans., 2014, 43, 4048-4058.

15 G. Maayan and G. Christou, Inorg. Chem., 2011, 50, 7015-7021.

16 D. S. Nesterov, V. N. Kokozay, J. Jezierska, O. V. Pavlyuk, R. Boča and A. J. L. Pombeiro, Inorg. Chem., 2011, 50, 4401-4411.

17 J. S. Kanady, E. Y. Tsui, M. W. Day and T. Agapie, Science, 2011, 333, 733-736.

18 D. I. Alexandropoulos, L. Cunha-Silva, L. Pham, V. Bekiari, G. Christou and T. C. Stamatatos, Inorg. Chem., 2014, 53, 3220-3229.

19 X. Yang, Z. Li, S. Wang, S. Huang, D. Schipper and R. A. Jones, Chem. Commun., 2014, 50, 15569-15572.

20 J. Jankolovits, C. M. Andolina, J. W. Kampf, K. N. Raymond and V. L. Pecoraro, Angew. Chem., Int. Ed., 2011, 50, 9660-9664.

21 G. Guthausen, J. R. Machado, B. Luy, A. Baniodeh, A. K. Powell, S. Krämer, F. Ranzinger, M. P. Herrling, S. Lackner and H. Horn, Dalton Trans., 2015, 44, 5032-5040.

22 E. C. Sañudo and L. Rosado Piquer, Dalton Trans., 2015, 44, 8771-8780.

23 K. Liu, W. Shi and P. Cheng, Coord. Chem. Rev., 2015, 289290, 74-122.
24 A. J. Tasiopoulos and S. P. Perlepes, Dalton Trans., 2008, 5537-5555.

25 L. Zhao, J. Wu, H. Ke and J. Tang, Inorg. Chem., 2014, 53, 3519-3525.

26 V. Chandrasekhar, P. Bag, W. Kroener, K. Gieb and P. Müller, Inorg. Chem., 2013, 52, 13078-13086.

27 S. Hossain, S. Das, A. Chakraborty, F. Lloret, J. Cano, E. Pardo and V. Chandrasekhar, Dalton Trans., 2014, 43, 10164-10174.

28 V. Chandrasekhar, S. Das, A. Dey, S. Hossain, F. Lloret and E. Pardo, Eur. J. Inorg. Chem., 2013, 2013, 4506-4514.

29 M. Nematirad, W. J. Gee, S. K. Langley, N. F. Chilton, B. Moubaraki, K. S. Murray and S. R. Batten, Dalton Trans., 2012, 41, 13711-13715.

30 M. Towatari, K. Nishi, T. Fujinami, N. Matsumoto, Y. Sunatsuki, M. Kojima, N. Mochida, T. Ishida, N. Re and J. Mrozinski, Inorg. Chem., 2013, 52, 6160-6178.

31 M. Sarwar, A. M. Madalan, C. Tiseanu, G. Novitchi, C. Maxim, G. Marinescu, D. Luneau and M. Andruh, New J. Chem., 2013, 37, 2280-2292.

32 L.-L. Fan, F.-S. Guo, L. Yun, Z.-J. Lin, R. Herchel, J.-D. Leng, Y.-C. Ou and M.-L. Tong, Dalton Trans., 2010, 39, 1771-1780.

33 L. Zhao, S. Xue and J. Tang, Inorg. Chem., 2012, 51, 5994-5996.

34 L.-F. Zou, L. Zhao, Y.-N. Guo, G.-M. Yu, Y. Guo, J. Tang and Y.-H. Li, Chem. Commun., 2011, 47, 8659-8661.

35 F. Habib, G. Brunet, V. Vieru, I. Korobkov, L. F. Chibotaru and M. Murugesu, J. Am. Chem. Soc., 2013, 135, 13242-13245.

36 J.-P. Costes and C. Duhayon, Eur. J. Inorg. Chem., 2014, 4745-4749.

37 V. Gómez, L. Vendier, M. Corbella and J.-P. Costes, Inorg. Chem., 2012, 51, 6396-6404.

38 E. Loukopoulos, B. Berkoff, A. Abdul-Sada, G. J. Tizzard, S. J. Coles, A. Escuer and G. E. Kostakis, Eur. J. Inorg. Chem., 2015, 2646-2649.

39 B. Berkoff, K. Griffiths, A. Abdul-Sada, G. J. Tizzard, S. Coles, A. Escuer and G. E. Kostakis, Dalton Trans., 2015, 44, 12788-12795.

40 M. Andruh, Dalton Trans., 2015, 44, 16633-16653.

41 J. Wu, L. Zhao, P. Zhang, L. Zhang, M. Guo and J. Tang, Dalton Trans., 2015, 44, 11935-11942.

42 H. Wang, H. Ke, S.-Y. Lin, Y. Guo, L. Zhao, J. Tang and Y.-H. Li, Dalton Trans., 2013, 42, 5298-5303.

43 P. Zhang, L. Zhang, S.-Y. Lin and J. Tang, Inorg. Chem., 2013, 52, 6595-6602.

44 H. Ke, L. Zhao, Y. Guo and J. Tang, Dalton Trans., 2012, 41, 2314-2319.

45 H. Ke, L. Zhao, Y. Guo and J. Tang, Dalton Trans., 2012, 41, 9760-9765.

46 K. C. Mondal, A. Sundt, Y. Lan, G. E. Kostakis, O. Waldmann, L. Ungur, L. F. Chibotaru, C. E. Anson and A. K. Powell, Angew. Chem., Int. Ed., 2012, 51, 7550-7554.

47 K. C. Mondal, G. E. Kostakis, Y. Lan, W. Wernsdorfer, C. E. Anson and A. K. Powell, Inorg. Chem., 2011, 50, 11604-11611. 
48 K. C. Mondal, G. E. Kostakis, Y. Lan and A. K. Powell, Polyhedron, 2013, 66, 268-273.

49 H. Ke, L. Zhao, Y. Guo and J. Tang, Inorg. Chem., 2012, 51, 2699-2705.

50 H. Ke, W. Zhu, S. Zhang, G. Xie and S. Chen, Polyhedron, 2015, 87, 109-116.

51 R. Kannappan, D. M. Tooke, A. L. Spek and J. Reedijk, Inorg. Chim. Acta, 2006, 359, 334-338.

52 I. Nemec, M. Machata, R. Herchel, R. Boča and Z. Trávníček, Dalton Trans., 2012, 41, 14603-14610.

53 N. Kushwah, M. K. Pal, A. Wadawale, V. Sudarsan, D. Manna, T. K. Ghanty and V. K. Jain, Organometallics, 2012, 31, 3836-3843.

54 S. Saha, S. Pal, C. J. Gómez-García, J. M. Clemente-Juan, K. Harms and H. P. Nayek, Polyhedron, 2014, 74, 1-5.

55 M. Hasanzadeh, M. Salehi, M. Kubicki, S. M. Shahcheragh, G. Dutkiewicz, M. Pyziak and A. Khaleghian, Transition Met. Chem., 2014, 39, 623-632.

56 D. Dey, G. Kaur, A. Ranjani, L. Gayathri, P. Chakraborty, J. Adhikary, J. Pasan, D. Dhanasekaran, A. R. Choudhury, M. A. Akbarsha, N. Kole and B. Biswas, Eur. J. Inorg. Chem., 2014, 3350-3358.

57 K. Griffiths, C. W. D. Gallop, A. Abdul-Sada, A. Vargas, O. Navarro and G. E. Kostakis, Chem. - Eur. J., 2015, 21, 6358-6361.

58 P. King, R. Clerac, W. Wernsdorfer, C. E. Anson and A. K. Powell, Dalton Trans., 2004, 2670-2676.

59 G. E. Kostakis and A. K. Powell, Coord. Chem. Rev., 2009, 253, 2686-2697.

60 G. E. Kostakis, V. A. Blatov and D. M. Proserpio, Dalton Trans., 2012, 41, 4634-4640.

61 O. M. Yaghi, M. O'Keeffe, N. W. Ockwig, H. K. Chae, M. Eddaoudi and J. Kim, Nature, 2003, 423, 705-714.

62 R. Della Pergola, F. Demartin, L. Garlaschelli, M. Manassero, S. Martinengo, N. Masciocchi and D. Strumolo, Inorg. Chem., 1991, 30, 846-849.

63 D. Collini, F. F. De Biani, S. Fedi, C. Femoni, F. Kaswalder, M. C. Iapalucci, G. Longoni, C. Tiozzo, S. Zacchini and P. Zanello, Inorg. Chem., 2007, 46, 7971-7981.

64 J. L. Atwood and J. W. Steed, in Supramolecular Chemistry, 2nd Edition, 2009, p. 402.

65 S. Bhattacharya and B. K. Saha, CrystEngComm, 2011, 13, 6941-6944.

66 A. J. Close, P. Kemmitt, M. K. Emmerson and J. Spencer, Tetrahedron, 2014, 70, 9125-9131.

67 K. Branko and Z. Marija, Acta Chim. Slov., 2012, 59, 670-679.

68 G. T. Tigineh, Y.-S. Wen and L.-K. Liu, Tetrahedron, 2015, 71, 170-175.

69 J. Spencer, N. Anjum, H. Patel, R. Rathnam and J. Verma, Synlett, 2007, 2557-2558.

70 J. Spencer, C. B. Baltus, H. Patel, N. J. Press, S. K. Callear, L. Male and S. J. Coles, ACS Comb. Sci., 2011, 13, 24-31.
71 C. C. Stoumpos, T. C. Stamatatos, H. Sartzi, O. Roubeau, A. J. Tasiopoulos, V. Nastopoulos, S. J. Teat, G. Christou and S. P. Perlepes, Dalton Trans., 2009, 1004-1015.

72 G. S. Papaefstathiou, C. P. Raptopoulou, A. Tsohos, A. Terzis, E. G. Bakalbassis and S. P. Perlepes, Inorg. Chem., 2000, 39, 4658-4662.

73 T. C. Stamatatos, K. A. Abboud, S. P. Perlepes and G. Christou, Dalton Trans., 2007, 3861-3863.

74 G. C. Vlahopoulou, T. C. Stamatatos, V. Psycharis, S. P. Perlepes and G. Christou, Dalton Trans., 2009, 3646-3649.

75 W.-H. Zhu, Y. Zhang, Z. Guo, S. Wang, J. Wang, Y.-L. Huang, L. Liu, Y.-Q. Fan, F. Cao and S.-W. Xiang, RSC Adv., 2014, 4, 49934-49941.

76 J. Tönnemann, J. Risse, Z. Grote, R. Scopelliti and K. Severin, Eur. J. Inorg. Chem., 2013, 2013, 4558-4562.

77 A. D. Becke, J. Chem. Phys., 1993, 98, 1372-1377.

78 A. D. McLean and G. S. Chandler, J. Chem. Phys., 1980, 72, 5639-5648.

79 R. Krishnan, J. S. Binkley, R. Seeger and J. A. Pople, J. Chem. Phys., 1980, 72, 650-654.

80 A. J. H. Wachters, J. Chem. Phys., 1970, 52, 1033-1066.

81 P. J. Hay, J. Chem. Phys., 1977, 66, 4377-4384.

82 K. Raghavachari and G. W. Trucks, J. Chem. Phys., 1989, 91, 1062-1065.

83 T. Clark, J. Chandrasekhar, G. W. Spitznagel and P. V. R. Schleyer, J. Comput. Chem., 1983, 4, 294-301.

84 M. J. Frisch, J. A. Pople and J. S. Binkley, J. Chem. Phys., 1984, 80, 3265-3269.

85 P. Fuentealba, H. Preuss, H. Stoll and L. Von Szentpály, Chem. Phys. Lett., 1982, 89, 418-422.

86 U. Wedig, M. Dolg, H. Stoll and H. Preuss, Quantum Chemistry: The Challenges of Transition Metals and Coordination Chemistry, Dordrecht, 1986, pp. 79-89.

87 M. F. Summers, Coord. Chem. Rev., 1988, 86, 43-134.

88 M. Frisch, G. Trucks and H. Schlegel, Gaussian Inc., Wallingford, 2010.

89 http://jmol.sourceforge.net/.

90 S. J. Coles and P. A. Gale, Chem. Sci., 2012, 3, 683-689.

91 O. V. Dolomanov, A. J. Blake, N. R. Champness and M. Schröder, J. Appl. Crystallogr., 2003, 36, 1283-1284.

92 L. Palatinus and G. Chapuis, J. Appl. Crystallogr., 2007, 40, 786-790.

93 L. J. Farrugia, J. Appl. Crystallogr., 1999, 32, 837-838.

94 G. M. Sheldrick, Acta Crystallogr., Sect. A: Found. Adv., 2015, 71, 3-8.

95 G. M. Sheldrick, Acta Crystallogr., Sect. A: Found. Crystallogr., 2008, 64, 112-122.

96 A. L. Spek, J. Appl. Crystallogr., 2003, 36, 7-13.

97 C. F. Macrae, P. R. Edgington, P. McCabe, E. Pidcock, G. P. Shields, R. Taylor, M. Towler and J. Van De Streek, J. Appl. Crystallogr., 2006, 39, 453-457.

98 A. L. Spek, Acta Crystallogr., Sect. D: Biol. Crystallogr., 2009, 65, 148-155. 